\title{
Relaxation Training to Reduce Anxiety Due to The Covid- 19 Pandemic in Third Trimester Pregnant Women
}

\author{
Astri Mayasari \\ Bhakti Kencana University \\ astri.mayasari@bku.ac.id \\ Isviyanti \\ Bhakti Kencana University \\ Isviyanti@bku.ac.id
}

\begin{abstract}
Covid-19 is a virus that attacks the respiratory system and has spread globally with more than 39 million positive cases; hence, several countries have quarantined. This pandemic has impacted on the physical and mental health. Furthermore, pregnant women are at high risk during an infectious disease outbreak, with a fatality rate of $25 \%$ for Covid- 19 cases, hence, the concerns related to the growth and development of neonates. The results of previous studies showed that pregnant women experience psychological changes in the form of anxiety and depression during the pandemic. Therefore, the purpose of this study was to provide relaxation training to reduce anxiety due to the Covid- 19 pandemic. The experimental study design was used, where there were two groups, namely experimental and control with measurements of pre-test, post-test and follow-up. Furthermore, the sample included 20 pregnant women in the third trimester and the measuring instrument used was the State-Trait Anxiety Inventory (STAI) with 20 items. The relaxation training was given in stages with four meetings, and the results showed that it reduced anxiety due to the pandemic in the third trimester of pregnant women $(p=0.004)$.
\end{abstract}

Keywords: Relaxation Training, Pregnant women, COVID-19.

\section{Introduction}

Pregnancy is a vulnerable time with a risk of psychological disorders which increases several times (Kumala, 20I5), and each gestational age has different stages of changes in physiological and psychological conditions. Furthermore, alertness and anxiety increase as the day of birth approach in the third trimester, because mother feels anxious about her life and the baby's (Resmaniasih, 2014). According to WHO (2020), pregnant women and fetuses are at high-risk during infectious disease outbreaks. The fatality rate for cases of COVID-19 infection in pregnant women is about 25\%. This results in concerns related to the growth and development of neonates (Purwaningsih, 2020). According to Corbett et al. (2020), pregnant women had an increase in worries of more 
than $50.7 \%$, including concerns about pregnancy (66.7\%) and baby care (35\%). Also, they experienced psychological changes in the form of anxiety and depression during the COVID-19 pandemic (Ryan et al, 2020), which affected them during treatment until the postpartum period (Lim et al, 2020).

Anxiety and depression in pregnancy have many effects on pregnant women until the puerperium, which affects the health of mother and the fetus she is carrying. According to Ma-xuenmei (2019), the stress level or depression of mother during pregnancy is affected by the place of residence, work, environment, health conditions, and complications during pregnancy. Also, COVID-19 is a cause of depression in pregnant women, and the high incidence is a health emergency that causes anxiety, depression, and stress. Previous studies demonstrated that the COVID-19 outbreak had a negative impact on maternal depression and anxiety levels during pregnancy (Ayaz R \& Hocaoğlu $M, 2020)$. In addition, pregnant women with depression affect the psychology of the unborn child, who tend to have suicidal behavior (Dadi, 2020). The long-term of untreated mental health disorders affects the health care of the women and fetus during pregnancy, hence, a strategy is needed to promote prevention and treatment (Cameron et al, 2020). Relaxation is a psychological intervention that is performed to reduce the anxiety level of pregnant women. This strategy is effective in an individual's resistance to stress and anxiety (Toosi, Akbarzadeh, \& Ghaemi, 2017).

According to a scientific view, relaxation is a technique to reduce stress and tension by stretching the whole body to achieve a healthy mental state (Varvogli \& Darviri, 20I I). This can be combined with methods that involve cognition, such as psychoeducation, visualization, and positive thinking (Annatagia, Retnowati, 20II). However, the intervention used in this study was based on the concept of Cognitive Behavioral Stress Management, which is a development of cognitivebehavioral therapy. Furthermore, pregnant women were trained on relaxation techniques with deep breathing in the working area of Babakan Public Health Center. The training begins with psychoeducation about stress and anxiety, followed by instruction and practice of deep breathing relaxation techniques. The relaxation stage is also given more time because study conducted by 
Alipoor (2017) and Rahimi (2014) showed its effectiveness in reducing anxiety in pregnant women.

Relaxation training reduces anxiety in different populations, such as breast cancer patients, female students, athletes, and breastfeeding mothers (Annatagia \& Retnowati, 20I I). According to Kai Liu et al. (2020), this training can reduce anxiety and improve sleep quality in COVID-I9 patients. In a sample of pregnant women, it can reduce stress, anxiety, and depression (Alipoor et al, 20I7). These previous studies showed the effectiveness of relaxation in pregnant women. Therefore, this study focus on identifying the effectiveness of relaxation training on anxiety, specifically in pregnant women. The study on relaxation training has been performed abroad and in Indonesia, such as the effect of hypnobirthing relaxation techniques on reducing labor pain (Ardhiyanti \& Safitiri, 2015) and the effect of guided imagery and music relaxation exercises to reduce anxiety in pregnant women facing childbirth (Murni et al., 20I4). However, there have been no recent study, specifically during the COVID-19 pandemic. Previous studies used relaxation techniques with other techniques, while this study focused on the use of Cognitive Behavioral Stress Management, where the technique is expected to reduce anxiety due to the COVID-19 pandemic in pregnant women.

\section{Method}

Participants

About 20 third-trimester pregnant women with anxiety scores (STAI) participated and were categorized as moderate and severe. The respondents filled out an informed consent form that they were willing to be a participant in the study conducted. Furthermore, the participants were divided into 2 groups, the treatment and control groups, each containing 10 participants aged I840 years, with married status. 
Table I

Results of participant screening in four Villages in Babakan Sub-district, Mataram City

$\begin{array}{ll}\text { Village } & \begin{array}{c}\text { Number of pregnant } \\ \text { women with gestational }\end{array}\end{array}$
age $>27$ weeks

\begin{tabular}{cccc}
\hline & & Moderate & Severe \\
\hline Babakan Timur & 10 & 7 & - \\
Abian tubuh & 11 & 4 & - \\
Cakra Selatan & 9 & 5 & - \\
Dasan Cermen & 13 & 4 & - \\
\hline Total & 43 & 20 & - \\
\hline
\end{tabular}

Study design

This is an experimental study (quasi-experimental) that involves comparing the treatment (experimental group) and comparison groups (control group) using pre-test, post-test, and follow-up measures.

\section{Study Measurement Tools}

State-Trait Anxiety Inventory (STAl) was used as the measuring instrument in this study. This instrument collects information about the perceived anxiety level with choices on a scale of I (rarely) to 4 (almost always). STAl was developed by Spielberger and has been used in several studies on anxiety themes. Furthermore, the internal consistency coefficient of STAI ranges from 0.86 to 0.95 , and examples of items in STAI are "I feel calm", "I feel tense", and "I feel afraid". STAI questionnaire scores ranged from 20 to 80 points and were divided into four groups, which include mild $(<35)$, moderate $(35-60)$, and severe anxiety $(60-80)$. This study used 20 state items to observe the state of anxiety due to the COVID-19 pandemic.

\section{Intervention}

The training carried out in a group setting lasted for four meetings. Furthermore, the experimental group received treatment in the form of relaxation training and then the follow-up measurements in both groups were completed. This training was given to the control group and each meeting lasted for 120 minutes was carried out 2 times a week. At the first meeting, the 
material provided was psychoeducation regarding the knowledge about COVID-19 and midwifery care during pregnancy as well as psychoeducation on stress and anxiety. The material at the second meeting was deep breathing and integrated imagery relaxations. Meanwhile, the third and fourth meetings, it was visualization and positive thinking, respectively, and the participants were given deep breathing relaxation exercises.

\section{Data analysis}

The data analysis was performed using SPSS software version 22.0 and descriptive and inferential statistical methods. Furthermore, the statistical significance level was set at $P<0.05$, and an independent t-test was used to compare the average anxiety score before and after the intervention.

\section{Result}

The post-test results in the experimental and control group as shown in Table 2 showed that ten participants in the experimental group experienced a decrease in anxiety scores, while five participants in the control group experienced a decrease in anxiety scores and they did not change the category of anxiety experienced.

Table 2

Description of the research data on participants' anxiety scores

\begin{tabular}{lccccc}
\hline Participants & Pre Test & Category & Post Test & Category & $\begin{array}{c}\text { Gain Score } \\
\text { (post-test - pre-test) }\end{array}$ \\
\hline Experiment & & & & & \\
\hline F & 41 & moderate & 32 & mild & -9 \\
M & 35 & moderate & 30 & mild & -5 \\
WR & 35 & moderate & 29 & mild & -6 \\
ML & 37 & moderate & 31 & mild & -6 \\
I & 36 & moderate & 30 & mild & -6 \\
IR & 49 & moderate & 40 & moderate & -9 \\
H & 46 & moderate & 38 & moderate & -8 \\
NK & 39 & moderate & 32 & mild & -7 \\
YA & 35 & moderate & 28 & mild & -7 \\
S & 38 & moderate & 30 & mild & -8 \\
\hline
\end{tabular}




\begin{tabular}{|c|c|c|c|c|c|}
\hline \multicolumn{6}{|c|}{ Control } \\
\hline$R$ & 45 & moderate & 42 & moderate & -3 \\
\hline 0 & 41 & moderate & 39 & moderate & -2 \\
\hline$S$ & 40 & moderate & 40 & moderate & 0 \\
\hline MY & 44 & moderate & 39 & moderate & -5 \\
\hline ST & 44 & moderate & 42 & moderate & -2 \\
\hline $\mathrm{MH}$ & 35 & moderate & 35 & moderate & 0 \\
\hline YL & 36 & moderate & 36 & moderate & 0 \\
\hline$R L$ & 35 & moderate & 35 & moderate & 0 \\
\hline AS & 38 & moderate & 37 & moderate & -1 \\
\hline$Y$ & 36 & moderate & 36 & moderate & 0 \\
\hline
\end{tabular}

This study conducted a homogeneity test to determine whether the variance of the data population was the same or not. The results in the control and experimental groups demonstrated that the significance score of the quality of life in the pre-test, post-test, and followup was $0.75 \mathrm{I}, 0.582$, and 0.455 , respectively. Therefore, this shows that the score is greater than 0.05 , indicating that the control and experimental groups have the same variance on the anxiety variable.

Table 3

The homogeneity test results of anxiety data

\begin{tabular}{lcc}
\hline & Levene Statistic & Sig. \\
\hline Pre test anxiety & 0,104 & 0,751 \\
\hline Post test anxiety & 0,314 & 0,582 \\
\hline Follow up anxiety & 0,584 & 0,455 \\
\hline
\end{tabular}

The hypothesis test was conducted using a nonparametric method with the Mann Whitney analysis because the subjects were small in number. Furthermore, the hypothesis proposed that the treatment group (experimental group) has a decreased anxiety score than the control group on the measurement after therapy.

Table 4

Different Anxiety Score Test

\begin{tabular}{lccc}
\hline Group & $\mathrm{N}$ & $\mathrm{Z}$ & Significance Level \\
\hline Experiment & 10 & $-2,845$ & 0,004 \\
Control & 10 & & \\
\hline
\end{tabular}

Note: significance level $p<0.05$ 
The results of the Mann-Whitney U-Test analysis in Table 4 showed a p-value of 0.004 . From these results, it can be concluded that there is a significant difference in the anxiety scores between the experimental and control groups after being treated in the form of Relaxation Training.

\section{Discussion}

Pregnant women in the third trimester are prone to psychological problems, such as anxiety, specifically with the pandemic. Hence, an intervention to reduce anxiety is required during the current Covid-19 pandemic. The results showed that there was a difference in anxiety between the experimental and the control group after the intervention $(p=0.004)$, indicating that relaxation reduced anxiety due to the Covid-19 pandemic in the third trimester of pregnant women.

This is in line with study by Alipoor et al. (2017) that effective relaxation techniques reduce anxiety in pregnant women. Also, it reduces anxiety and improves sleep quality in patients with Covid-19 (Kai Liu, 2020). According to Kim and Kim (2017), relaxation therapy is effective as a treatment for individuals with anxiety disorders. Hence, pregnancy is a period of great change in life, and pregnant women in the third trimester are required to care for themselves and the fetus to achieve a smooth delivery process. Vulnerability is also increased by isolation, social restrictions, and extreme changes during a pandemic, specifically in vulnerable populations such as pregnant women (Saccone et al, 2020).

Participants who practice deep breathing relaxation, feel calmer and their heart rate is regular. According to Hamasaki (2020), deep breathing increases fluctuations in blood pressure and heart rate, thereby increasing baroreflex sensitivity, heart rate variability, and blood pressure. Relaxation is a condition in which the body's muscles stretches, resulting in a comfortable sensation. This is because the relaxation of breathing suppresses the adrenaline hormone in the body, leading to an increase in endorphins (Jonzhuo, 2021). 
In the following session, the participants performed integrated imagery (visualization) with breathing relaxation. They were trained to reinterpret negative thoughts about current conditions that make them feel anxious. Therefore, visualization significantly relieves anxiety and improves sleep quality in hemodialysis patients (Afshar et al, 2018).

An approach to dealing with anxiety is to practice positive thinking. This training improves the mental and psychological conditions of individuals, directing them to have positive self-experience and character. Generally, positive beliefs have a good relationship with various aspects of health and it plays an important role in preventing physical and mental disorders and improving mental health status (Shokrpour et al, 202I). Furthermore, practicing positive thinking increases the ability to manage stress and emotions by increasing self-awareness, the ability to adapt, and reducing anxiety (Beiranvand, 2019).

The limitations in this study are threats to internal validity, including experience and family support. Two measurements were conducted, namely before and after training, with short intervals resulting in familiarity with the testing instrument (scale). In addition, this study was limited to pregnant women, hence, they cannot be generalized to other populations. Therefore, future studies can develop relaxation training in other populations with larger participants.

\section{Conclusion}

The relaxation training reduces anxiety due to the COVID-19 pandemic in the third trimester of pregnant women. This can be conducted as an intervention program for pregnant women with anxiety and performed by other health workers. 


\section{Acknowledgement}

This study was funded by the Ministry of Research and Technology/ National Agency for research and Innovation through the "Hibah Penelitian Dasar Unggulan Perguruan Tinggi" research grant 2018-2020.

\section{REFERENCES}

Afshar, M., Mohsenzadeh, A., Gilasi, H., \& Sadeghi-Gandomani, H. (20I8). The Effects of guided imagery on state and trait anxiety and sleep quality among patients receiving hemodialysis: a randomized controlled trial. Complementary Therapies in Medicine 4, 37-4I. https://doi.org//0.1016/j.ctim.2018.07.006.

Alipour M, Ghahremani L, Amooee S, \& Keshavarzi S. (2017). The effectiveness of relaxation techniques on depression, anxiety and stress in pregnant women: based on self-efficacy theory. Scientific Journal of Kurdistan University, 22(3), 20-30.

Apostolo, J. L. A., \& Kolcaba, K. (2009). The effects of guided imagery on comfort, depression, anxiety, and stress of psychiatric inpatients with depressive disorder. Archives of Psychiatric Nursing 23 (6), 403-4II. https://doi.org/10.1016/j.apnu.2008.12.003

Ardhiyanti, Y., \& Safitri, L. (20I5). Pengaruh teknik relaksasi hypnobirthing terhadap penurunan rasa nyeri kala I persalinan normal pada primipara di BPM Evi. Jurnal Maternity and Neonatal 2(2)

Ayaz, R., Hocaoğlu, M., Günay, T., Yardımcı, O. D., Turgut, A., \& Karateke, A. (2020). Anxiety and depression symptoms in the same pregnant women before and during the COVID-19 pandemic. Journal of Perinatal Medicine, 48(9), 965-970. https://doi.org//0.1515/jpm-2020$\underline{0380}$.

Beiranvand, M., Moghadam, M.K., Sabounchi, R., Delphan, M., Ghafuori A, Keramati Moghadam, R. (2019). The effectiveness of positive thinking training on self-efficacy and emotion regulation in men with hemophilia. Trends Med. 19, I-5.

Cameron, E. E., Joyce, K. M., Delaquis, C. P., Reynolds, K., Protudjer, J., \& Roos, L. E. (2020). Maternal psychological distress \& mental health service use during the COVID-19 pandemic. Journal of Affective Disorders, 276, 765-774. https://doi.org//0.1016/j.jad.2020.07.08I

Corbett, G. A., Milne, S. J., Hehir, M. P., Lindow, S. W., \& O'connell, M. P. (2020). Health anxiety and behavioural changes of pregnant women during the COVID-19 pandemic. European journal of obstetrics, gynecology, and reproductive biology, 249, 96-97. https://doi.org//0.1016/j.ejogrb.2020.04.022 


\section{Journal of Educational, Health and Community Psychology Mayasari, \\ Vol I0, No 4, 202 I E-ISSN 2460-8467 Isviyanti.}

Dadi A F, Miller E R, Bisetegn T A, \& Mwanri, L. (2020). Global burden of antenatal depression and its association with adverse birth outcomes: an umbrella review. BMC Public Health, 20(I), 173. https://doi.org/10.1186/s12889-020-8293-9.

Ryan, G.A., Purandare, N.C., McAuliffe, F.M., Hod, M. \& Purandare, C.N. (2020), Clinical update on COVID-19 in pregnancy: A review article. J. Obstet. Gynaecol. Res., 46, I2351245. https://doi.org//0.1 I | //jog.14321.

Hamasaki, H. (2020). Effects of diaphragmatic breathing on health: A narrative review. Journal Medicines 7, 65. doi:10.3390/medicines7100065

Jounzhou, \& Xing-ting Feng. (202I). Relaxation behaviour of Jinping marble under true triaxial stresses: International Journal of Rock Mechanics and Mining Sciences: https://doi.org/10.1016/j.ijrmms

Liu, K., Chen, Y., Wu, D., Lin, R., Wang, Z., \& Pan, L. (2020). Effects of progressive muscle relaxation on anxiety and sleep quality in patients with COVID-19. Complementary therapies in clinical practice, 39, I0II32. https://doi.org/10.1016/j.ctcp.2020.101132.

Kim, H., \& Kim, E. (2018). Effects of relaxation therapy on anxiety disorders: a systematic review and meta-analysis. Archives of Psychiatric Nursing, 32(2): 278-284. https://doi.org/10.1016/j.apnu.2017.11.015

Kumala, F.T. (20I5). Hubungan antara kejadian preeklampsia dan resiko depresi antenatal di RSI Sunan Kudus. Unpublished Masteral thesis, Universitas Sebelas Maret Surakarta

Kurki, T., Hiilesmaa, V., Raitasalo, R., Mattila, H., \& Ylikorkala, O. (2000). Depression and anxiety in early pregnancy and risk for preeclampsia. Obstetrics and Gynecology, 95(4), 487-490. https://doi.org/10.1016/s0029-7844(99)00602-x.

Dashraath, P., Wong, J., Lim, M., Lim, L. M., Li, S., Biswas, A., Choolani, M., Mattar, C., \& Su, L. L. (2020). Coronavirus disease 2019 (COVID-19) pandemic and pregnancy. American journal of obstetrics and gynecology, 222(6), 52I-53I. https://doi.org/10.1016/j.ajog.2020.03.021.

Xuemei, M., Ying, W., Hua, H., Xuguang, T., Yunhui, Z., Huijing, S. (2019). The impact of resilience on prenatal anxiety and depression among pregnant women in Shanghai. Journal of Effective Disorders, 250, 57-64. https://doi.org/10.1016/j.jad.2019.02.058

Murni, N.N.A., Suhartono, \& Suherni, Titi. (20I4). Pengaruh latihan relaksasi guided imagery and music (GIM) pada kelas ibu terhadap derajat kecemasan ibu hamil menghadapi persalinan pertama: studi di Puskesmas Meninting Kabupaten Lombok Barat. Jurnal Kesehatan Prima 8(I), I I 97-I 206.

Purwaningsih, H. (2020). Analisis masalah psikologis pada ibu hamil selama masa pandemi covid19: literature review. Call for Paper Seminar Nasional Kebidanan. Retrieved November http://jurnal.unw.ac.id: I 254/index.php/semnasbidan/article/view/639

Rahimi, F. (20I4). Effect of relaxation training on pregnancy anxiety in high risk women. Safety Promotion and Injury Prevention 2(3), I80-I 88. 
Resmaniasih, K. (20I4). Pengaruh teknik pernapasan diafragma terhadap kecemasan pada ibu hamil trimester III. Unpublished masteral thesis, Universitas Dipenogoro.

Sacccone, G., Venturella, R., Chiara de Angells, M., \& Bifulco, G. (2020). Psychological impact of COVID-19 in pregnant women. American Journal of Obstetrics and Gynecology. DOI: 10.1016/j.ajog.2020.05.003

Shokrpour, N., et al. (202I). Effect of positive thinking training on stress, anxiety, depression, and quality of life among hemodialysis patients: A randomized controlled clinical trial. Journal of Education and Health Promotion, 10, 225-235. doi: 10.4103/jehp.jehp_II20_20

Varvogli, L., \& Darviri, C. (20I I). Stress management techniques: Evidence-based procedures that reduce stress and promote health, Health Science Journal, 5(2), pp 74-89

WHO (2020). Covid-19 and pregnancy interim guidance. Retrieved from: https://data2.unhcr.org/en/documents/download/76078 